\title{
Dynamics of Renal Electrolyte Excretion in Growing Mice
}

\author{
Katharina Schmidt Maria Ripper Ines Tegtmeier Evelyn Humberg \\ Christina Sterner Markus Reichold Richard Warth Sascha Bandulik
}

Medical Cell Biology, University of Regensburg, Regensburg, Germany

\begin{abstract}
Key Words
Genetically modified mice $\cdot$ Growing mice $\cdot$ Postnatal

dynamics $\cdot$ Renal electrolyte excretion
\end{abstract}

\begin{abstract}
Genetically modified mice represent important models for elucidating renal pathophysiology, but gene deletions frequently cause severe failure to thrive. In such cases, the analysis of the phenotype is often limited to the first weeks of life when renal excretory function undergoes dramatic physiological changes. Here, we investigated the postnatal dynamics of urinary ion excretion in mice. The profiles of urinary electrolyte excretion of mice were examined from birth until after weaning using an automated ion chromatography system. Postnatally, mice grew about $0.4 \mathrm{~g} /$ day, except during two phases with slower weight gain: (i) directly after birth during adaptation to extrauterine conditions (P0-P2) and (ii) during the weaning period (P15-P21), when nutrition changed from mother's milk to solid chow and water. During the first 3 days after birth, remarkable changes in urinary $\mathrm{Na}^{+}, \mathrm{Ca}^{2+}, \mathrm{Mg}^{2+}$, and phosphate concentrations occurred, whereas $\mathrm{K}^{+}$and $\mathrm{Cl}^{-}$concentrations hardly changed. From days 4-14 after birth, $\mathrm{Na}^{+}$, $\mathrm{Ca}^{2+}, \mathrm{Mg}^{2+}, \mathrm{K}^{+}$, and $\mathrm{Cl}^{-}$concentrations remained relatively stable at low levels. Urinary concentrations of creatinine, $\mathrm{NH}_{4}{ }^{+}$, phosphate, and sulfate constantly increased from birth until after weaning. Profiles of salt excretion in $\mathrm{KCNJ} 10^{-/-}$mice exemplified the relevance of age-dependent analysis of urinary
\end{abstract}

excretion. In conclusion, the most critical phases for analysis of renal ion excretion during the first weeks of life are directly after birth and during the weaning period. The age dependence of urinary excretion varies for the different ions. This should be taken into consideration when the renal phenotype of mice is investigated during the first weeks of life.

(C) 2013 S. Karger AG, Basel

\section{Introduction}

During the last decades, genetically modified mice have become important tools to study the role of specific renal proteins and findings from those studies have largely improved our understanding of kidney physiology [1]. Unfortunately, genetically modified mice are often severely affected by the gene deletion, e.g. by severe renal salt wasting, and some knockout mice hardly survive until weaning. In such mouse models, characterization of the renal excretory function is only possible during the first weeks after birth or requires rescuing of the animals by continuous replacement of fluid and salt losses [2-8].

Researchers have to be aware of the dramatic physiological changes of kidney function in young mice. Kidney development is still in progress at the time of birth and

Katharina Schmidt and Maria Ripper contributed equally.

\begin{tabular}{ll}
\hline KARGER & $\begin{array}{l}\text { ○ 2013 S. Karger AG, Basel } \\
1660-2137 / 13 / 1244-0007 \$ 38.00 / 0 \quad \text { Karger }\end{array}$ \\
E-Mail karger@karger.com & $\begin{array}{l}\text { This is an Open Access article licensed under the terms of the } \\
\text { Creative Commons Attribution-NonCommercial 3.0 Un- } \\
\text { ported license (CC BY-NC) (www.karger.com/OA-license), } \\
\text { applicable to the online version of the article only. Distribu- } \\
\text { tion permitted for non-commercial purposes only. }\end{array}$
\end{tabular}




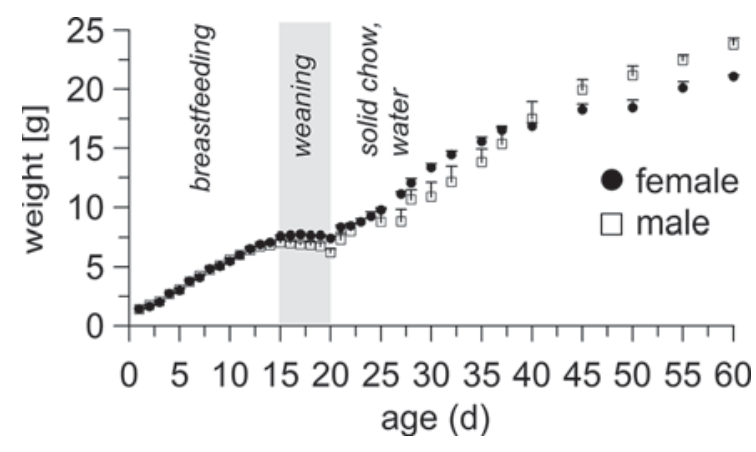

Fig. 1. a Growth curve of male and female C57/BL/6J mice during postnatal development. The weaning phase, when nutrition changes from mother's milk to solid chow and water, is highlighted by a gray background. b Renal histology of newborn and adult mice. Hematoxylin and eosin staining demonstrates dramatic morphological changes of kidneys during development. Neonate kidneys show a lower degree of tubular organization than adult kidneys, which expose a typical zonation of cortex and medulla. Subcapsular region in neonates represents a dense proliferative zone with glomeruli and tubuli at different stages of maturation.

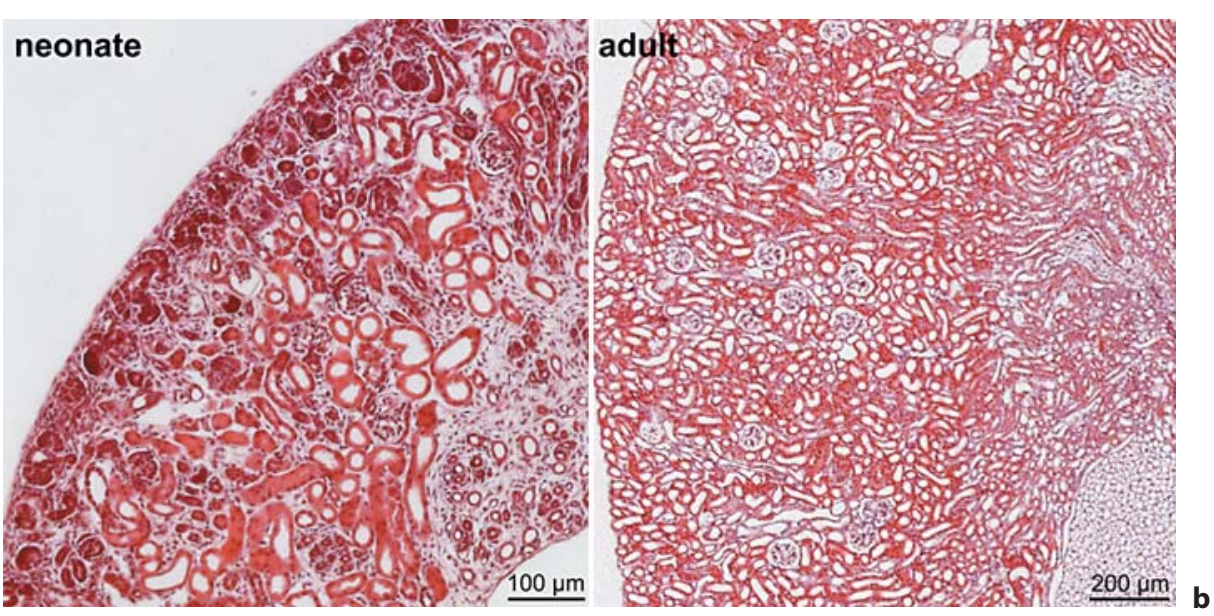

the ability of the kidneys to produce diluted or concentrated urine, to reabsorb and to excrete electrolytes is limited $[9,10]$. Moreover, growing mice have to face two major challenges - the switch from intrauterine to postnatal conditions and the period of weaning when the diet changes from mother's milk to solid chow and water. The rapid growth of the animals also interferes with electrolyte and water balance, e.g. during the first week of life mice gain up to $20 \%$ of body weight per day.

This study aimed at giving an outline of the age-dependent variations of the urinary excretion of electrolytes in mice. These data could be helpful for researchers investigating the renal function in growing mice.

\section{Methods}

\section{Animals and Animal Experimentation}

C57BL6 mice were maintained on a regular 12-hour light period with free access to a standard mouse diet (mixture of rodent diet V1324-000 (33\%) and V1535-000 (67\%), both from ssniff-Spezialdiäten $\mathrm{GmbH}$, Soest, Germany) and water. Mouse anesthesia was carried out as described elsewhere [11]. Growth curves of the mice were recorded by weighing, and urine samples were collected by suprapubic puncture of the urinary bladder in neonates or from spot urine from elder mice up to the age of 60 days. In total, 669 samples from 117 different mice, derived from 9 different litters, were analyzed. The experimental protocols were approved by the local councils for animal care and were conducted according to the German laws for animal care and the NIH Guide for the Care and Use of Laboratory Animals. $\mathrm{KCNJ1} 10^{-/-}$mice [12] were kindly provided by Dr. Clemens Neusch and Dr. Frank Kirchhoff, Max Planck Institute for Experimental Medicine, Gottingen, Germany.

\section{Quantification of Inorganic Ions and Creatinine in Urine} Samples

Anions $\left(\mathrm{Cl}^{-}\right.$, phosphate, sulfate), cations $\left(\mathrm{Na}^{+}, \mathrm{NH}_{4}{ }^{+}, \mathrm{K}^{+}, \mathrm{Mg}^{2+}\right.$, $\left.\mathrm{Ca}^{2+}\right)$, and creatinine were quantified in urine samples using an automated ion chromatography system (Dionex/Thermo Fisher Scientific, Idstein, Germany; further details to the instrumentation are given in the supplementary information; for all online suppl. material, see www.karger.com/doi/10.1159/000356816).

\section{Histology of Mouse Kidney}

Mice were fixated by a paraformaldehyde-containing solution as described elsewhere [11]. Paraffin-embedded kidneys were obtained according to standard protocols. For visualization of the histology, 5- $\mu \mathrm{m}$ kidney sections were stained with hematoxylin (Mayer's hemalum) and eosin. 


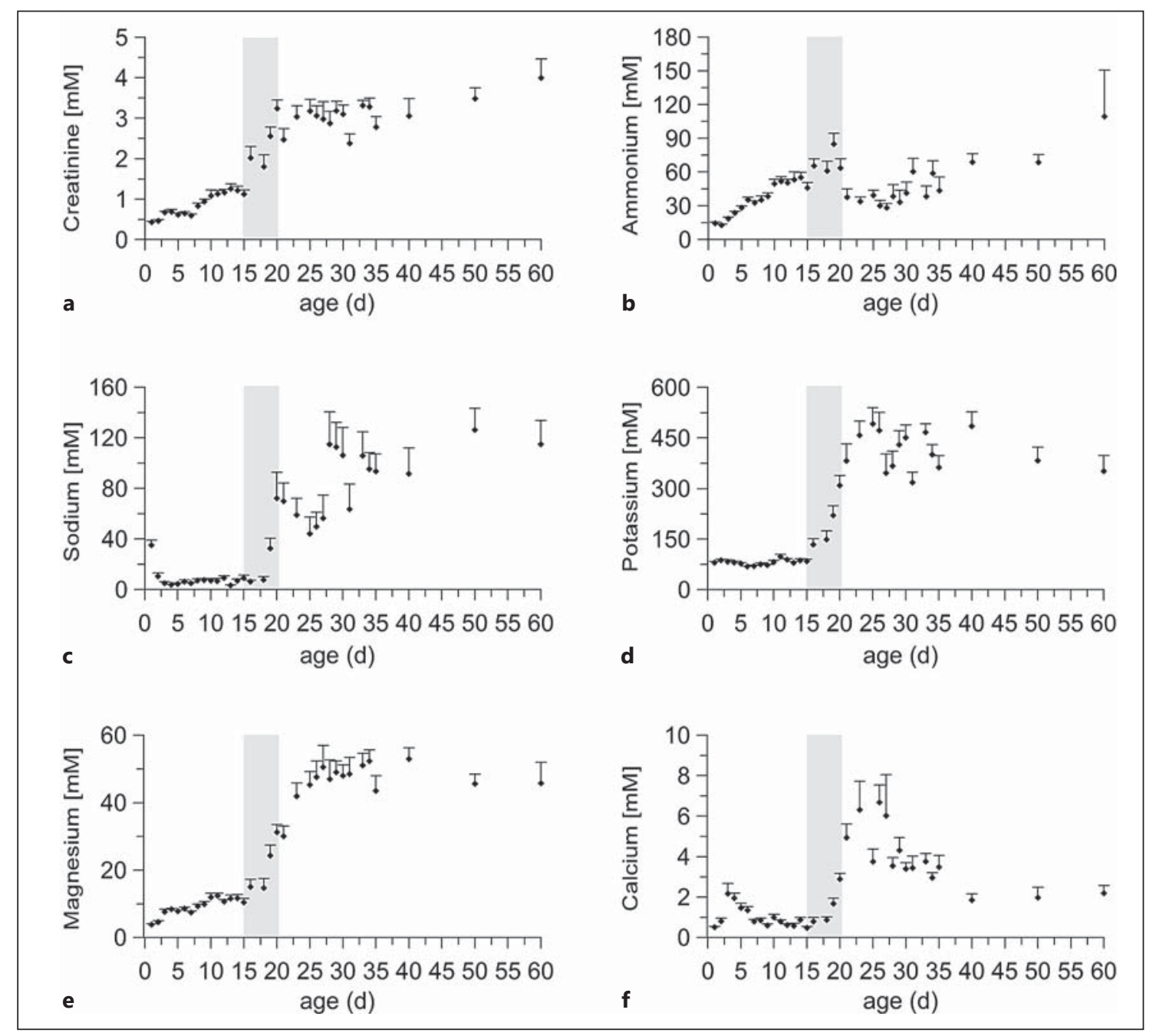

Fig. 2. Urinary concentration of creatinine (a) and different cations $\left(\mathrm{NH}_{4}^{+}, \mathrm{Na}^{+}, \mathrm{K}^{+}, \mathrm{Mg}^{2+}\right.$ and Ca $\left.{ }^{2+}\right)(\mathbf{b}-\mathbf{f})$ during postnatal development of mice. The weaning phase is highlighted by a gray background. Data are shown separately for male and female mice in online supplementary figure 1.

\section{Statistics}

Data are shown as mean values \pm SEM from ' $n$ ' observations. Unpaired Student's $t$ test was used and a $p$ value of $<0.05$ was accepted to indicate statistical significance.

\section{Results}

\section{Postnatal Growth}

Postnatal development and growth of mice are very dynamic processes (fig. 1). Starting with $1.4 \mathrm{~g}$ at postnatal day P1, C57BL6 mice showed a 15- to 17-fold increase in body weight during the first 8 weeks after birth. After an initial delay of growth after birth, mice of both sexes gained weight in an almost linear way by $0.4 \mathrm{~g} /$ day up to day P14. Around P15-P20, mice stopped growing. This phase of slow weight gain reflected the weaning phase when mice reduced or stopped drinking mother's milk and adapted to solid chow and tap water. The weight gain was more delayed in male mice as evidenced by a lower mean weight of $6.2 \pm 0.3 \mathrm{~g}$ compared to female mice with $7.4 \pm 0.2 \mathrm{~g}$ at day P20. Their growth continued almost linear after weaning. After the 6 th postnatal week, the weight of male mice exceeded that of female mice.

\section{Urinary Concentrations of Creatinine}

In order to gain closer insights into the electrolyte balance of growing mice, we measured the renal excretion of various ions and creatinine in the urine by ion chroma- 


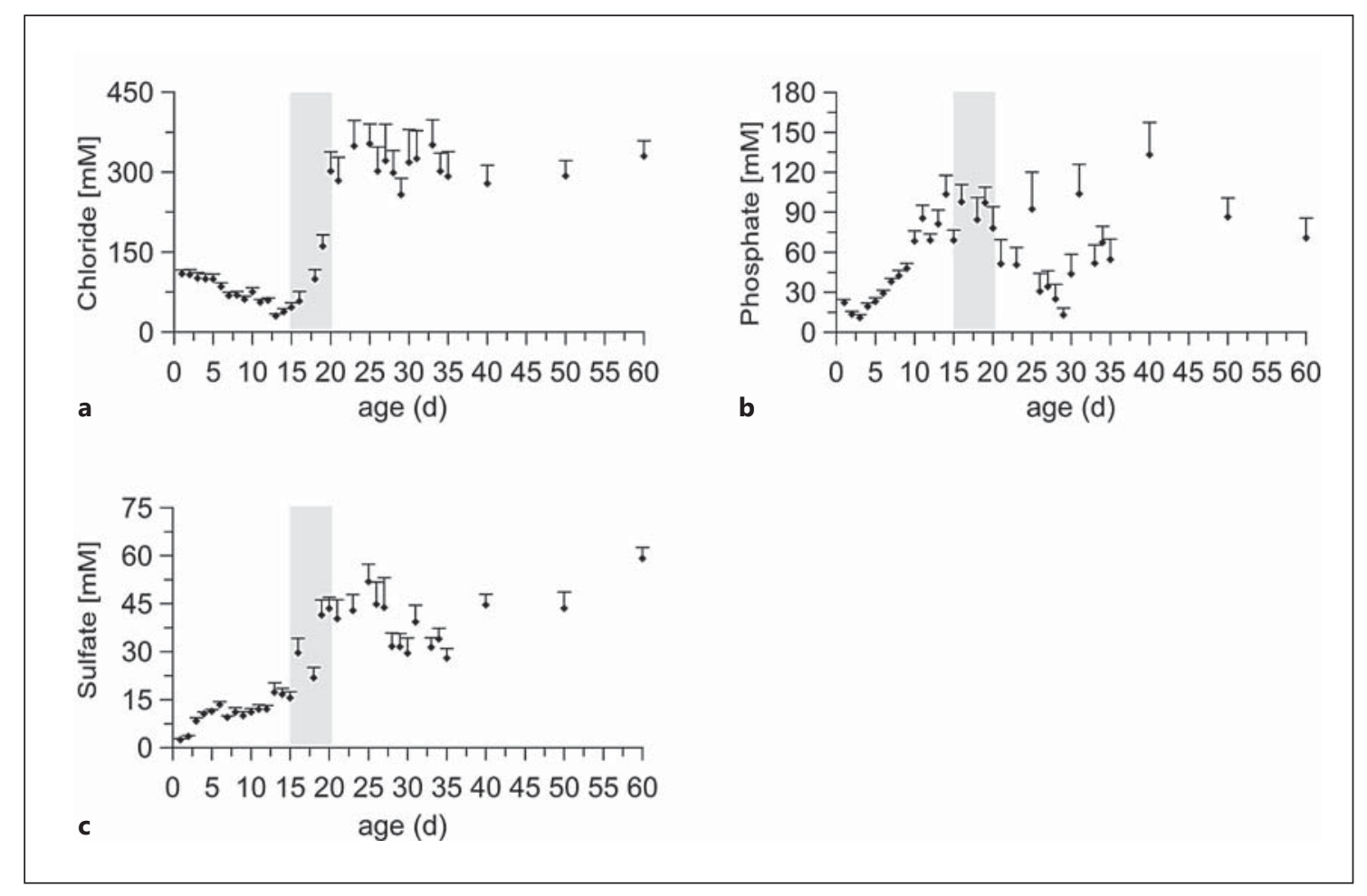

Fig. 3. Urinary concentration of $\mathrm{Cl}^{-}$(a), phosphate (b), and sulfate (c) during postnatal development of mice. The weaning phase is highlighted by a gray background. Data are shown separately for male and female mice in online supplementary figure 2 .

tography. The concentration of creatinine increased from $0.4 \mathrm{mmol} / \mathrm{l}$ after birth to $4 \mathrm{mmol} / \mathrm{l}$ in adult animals (fig. 2 ). During weaning (P15-P20) the creatinine concentration strongly increased from 1.2 to $3.2 \mathrm{mmol} / \mathrm{l}$. Significant differences between the sexes were not observed; separate data for male and female mice are shown in online supplementary figures 1 and 2 .

\section{Urinary Concentrations of Inorganic Cations}

Urinary concentrations of the cations $\mathrm{Na}^{+}, \mathrm{K}^{+}, \mathrm{Mg}^{2+}$, $\mathrm{Ca}^{2+}$, and $\mathrm{NH}_{4}{ }^{+}$are shown in figure 2. At birth, the urinary $\mathrm{Na}^{+}$concentration was about $35 \mathrm{mmol} / \mathrm{l}$, it decreased within 3 days to values $<10 \mathrm{mmol} / \mathrm{l}$ and remained low until the end of the lactation period. When mice started to eat solid chow during the weaning period, the urinary $\mathrm{Na}^{+}$concentration strongly increased up to $70 \mathrm{mmol} / \mathrm{l}$. After weaning, the urinary $\mathrm{Na}^{+}$concentration stayed high and was quite variable due to independent uptake of $\mathrm{Na}^{+}-$ containing chow and water. In contrast to $\mathrm{Na}^{+}$, urinary $\mathrm{K}^{+}$concentrations did not show the strong decrease during the first 3 postnatal days. $\mathrm{K}^{+}$concentrations were stable during the lactation period (about $80 \mathrm{mmol} / \mathrm{l}$ ) and increased markedly (up to $500 \mathrm{mmol} / \mathrm{l}$ ) during the weaning period. Urinary $\mathrm{Mg}^{2+}$ concentration showed the lowest values immediately after birth $(<5 \mathrm{mmol} / \mathrm{l})$ followed by a slow increase during the lactation period $(12 \mathrm{mmol} / \mathrm{l}$ at P14) and a strong increase during weaning (up to 50 $\mathrm{mmol} / \mathrm{l})$. Urinary $\mathrm{Ca}^{2+}$ concentrations showed a peak at day P3 after birth $(2.2 \mathrm{mmol} / \mathrm{l})$ followed by low urinary concentrations of $0.6-1 \mathrm{mmol} / \mathrm{l}$ in the second week after birth. The time course of the urinary ammonium concentration was different from those of the other cations; it increased constantly during the first weeks of life up to some $60 \mathrm{mmol} / \mathrm{l}$ during and after the weaning period. Online supplementary figure 3 shows the urinary concentrations of cations normalized to creatinine.

\section{Urinary Concentrations of Inorganic Anions}

Urinary $\mathrm{Cl}^{-}$concentrations constantly decreased during the first 2 weeks of life (from $110 \mathrm{mmol} / \mathrm{l}$ after birth to $40 \mathrm{mmol} / \mathrm{l}$ at P14). Similar to the time course of the $\mathrm{K}^{+}$ concentration, $\mathrm{Cl}^{-}$levels strongly increased during weaning (up to $350 \mathrm{mmol} / \mathrm{l}$ ). Urinary phosphate concentrations were minimal at day P3 after birth $(10 \mathrm{mmol} / \mathrm{l})$ and
10

Nephron Physiol 2013;124:7-13

DOI: $10.1159 / 000356816$
Schmidt/Ripper/Tegtmeier/Humberg/ Sterner/Reichold/Warth/Bandulik 
Fig. 4. Example of pathological urinary excretion profile in genetically modified newborn mice during the first 6 postnatal days. Urinary excretion of creatinine (a), $\mathrm{Ca}^{2+}$ (b), $\mathrm{Na}^{+}(\mathbf{c})$, and $\mathrm{K}^{+}$(d) of newborn KCNJ10 wild-type (white symbols, $\mathrm{n}=5-20$ ), heterozygous (gray symbols, $\mathrm{n}=5-31$ ), and knockout (black symbols, $\mathrm{n}=4-18$ ) mice is shown.
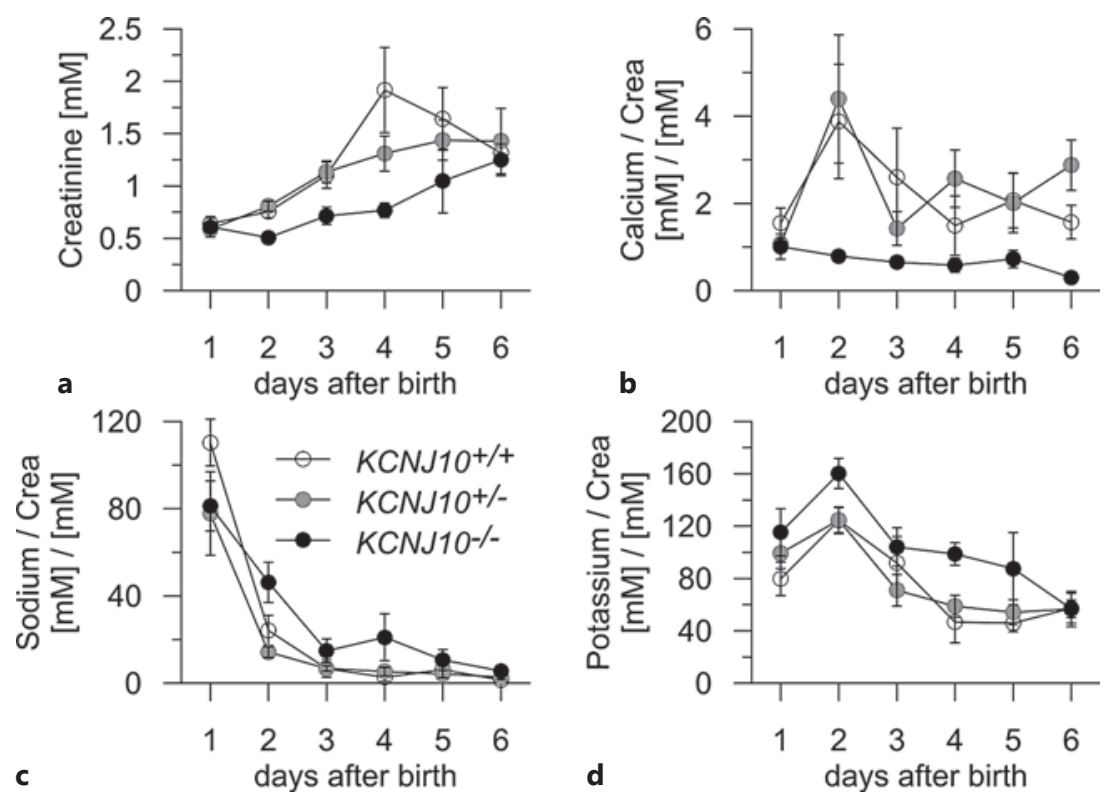

then increased continuously until weaning (100 $\mathrm{mmol} / \mathrm{l})$, similar to the time course of the urinary ammonium concentration. Urinary sulfate excretion was very low at birth $(2.5 \mathrm{mmol} / \mathrm{l})$ and increased continuously until after weaning ( $50 \mathrm{mmol} / \mathrm{l}$ at P25) (fig. 3). Online supplementary figure 4 shows the urinary concentrations of anions normalized to creatinine.

Salt-Wasting Phenotype of Newborn $\mathrm{KCNJ10}^{-/-}$Mice

$\mathrm{KCNJ10}$ is a basolateral potassium channel of renal distal convoluted tubules and loss of function mutations lead to EAST/SeSAME syndrome $[13,14]$ in humans. As an example of an age-dependent salt-wasting phenotype of genetically modified mice, we measured the excretion of creatinine, $\mathrm{Ca}^{2+}, \mathrm{Na}^{+}$, and $\mathrm{K}^{+}$during the first 6 days after birth (fig. 4). $\mathrm{KCNJ} 10^{-/-}$mice displayed, in an agedependent manner, reduced urinary creatinine concentration, increased urinary $\mathrm{Na}^{+}$and $\mathrm{K}^{+}$, but reduced excretion of $\mathrm{Ca}^{2+}$.

\section{Discussion}

Genetically modified mice as models for kidney diseases often show increased postnatal lethality and failure to thrive. In such cases, analysis of the renal function is restricted to the first weeks of life. This study depicts the physiological changes of urinary ion concentrations in growing C57BL6 mice.

\section{Dynamic Changes during the First Weeks after Birth}

The quantities of ions taken up during the lactation period are determined by composition and availability of mother's milk (suckling mice drink about $1.5 \mathrm{ml} /$ day of mother's milk (an estimate based on Knight et al. [15]). Growing mice have to retain most of the ingested ions to allow rapid gain of body weight. Accordingly, the urinary concentrations of $\mathrm{Na}^{+}, \mathrm{Cl}^{-}, \mathrm{K}^{+}, \mathrm{Ca}^{2+}$, and $\mathrm{Mg}^{2+}$ are much lower during the lactation period compared to weaning when mice take up ions with solid chow independently from water.

Moreover, the ion concentrations in the milk change during the course of lactation [16-18]. For instance, Nicholas and Hartmann [16] reported a marked increase of $\mathrm{Ca}^{2+}$ and phosphate concentrations in rat milk during the lactation period. Table 1 shows data from the literature about the range of ion concentrations in rodent milk. To our knowledge, precise profiles of ion composition in mouse milk during lactation were not reported but most probably there is also variation in mice which could influence the urinary ion concentration.

The remarkably high amounts of $\mathrm{Na}^{+}$excreted during the first 2 days after birth could result to some extent from the lower responsiveness of neonatal mice to aldosterone 
Table 1. Composition of mother's milk from mouse and rat

\begin{tabular}{lcc}
\hline & Mouse [26-34] & Rat $[16-18,35]$ \\
\hline $\mathrm{Na}^{+}, \mathrm{mmol} / \mathrm{l}$ & $24-43$ & $25-55$ \\
$\mathrm{~K}^{+}, \mathrm{mmol} / \mathrm{l}$ & $47-53$ & $25-50$ \\
$\mathrm{Mg}^{2+}, \mathrm{mmol} / \mathrm{l}$ & $8-10$ & $3-20$ \\
$\mathrm{Ca}^{2+}, \mathrm{mmol} / \mathrm{l}$ & $3-100$ & $17-68$ \\
$\mathrm{Cl}^{-}, \mathrm{mmol} / \mathrm{l}$ & 45 & $27-40$ \\
Phosphate, $\mathrm{mmol} / \mathrm{l}$ & 74 & $7-37$ \\
Protein, \% & $7-13$ & $6-12$ \\
Lipids/fat, \% & 10 & $11-18$ \\
\hline
\end{tabular}

Data were compiled from the literature and they include values from different days of lactation as well from different mouse and rat strains. In addition, different methods were used for the measurement of the ion concentrations. For detailed information, readers are referred to the original publications.

compared to adult mice [19]. The characteristic profiles of urinary $\mathrm{Ca}^{2+}$ and phosphate during the first postnatal week might be caused by multiple factors: (i) fetal suppression of the parathyroid hormone [4], (ii) initial decrease of plasma $\mathrm{Ca}^{2+}$ because of the separation from the maternal circulation, and (iii) recovery of plasma $\mathrm{Ca}^{2+}$ by supply with the $\mathrm{Ca}^{2+}$-rich mother's milk. The time course of $\mathrm{Mg}^{2+}$ excretion was different from that of $\mathrm{Ca}^{2+}$. In rats, postnatal renal handling of $\mathrm{Ca}^{2+}$ and $\mathrm{Mg}^{2+}$ also showed characteristic differences [20].

In mice the full capacity to mobilize sulfate from sulfur-containing amino acids develops only after birth [21]. The very low excretion of sulfate directly after birth and the constant increase during the lactation period probably result from the increased utilization of sulfate from mother's milk.

The capacity of the kidneys of newborns to excrete an excess of $\mathrm{K}^{+}$is low compared to adult animals/humans [9]. Nevertheless, urinary $\mathrm{K}^{+}$concentrations during the lactation period were very stable in the range of $80 \mathrm{mmol} / \mathrm{l}$ and they increased up to $500 \mathrm{mmol} / \mathrm{l}$ when mice start to eat solid chow. Urinary $\mathrm{Cl}^{-}$was the only ion examined for which the concentrations continuously decreased during the first 2 postnatal weeks. The postnatal maturation of renal $\mathrm{Cl}^{-}$transport systems probably contributes to this phenomenon [22]. The strong increase in urinary $\mathrm{Cl}^{-}$ during weaning is mostly caused by increased $\mathrm{Cl}^{-}$uptake via solid chow.

\section{Creatinine Excretion}

The urinary creatinine concentration was constantly increasing from low levels after birth to some 10-fold higher levels in adult animals (fig. 2). The concentration of creatinine in the urine depends on the amounts of excreted creatinine and excreted water. The amount of creatinine excreted is determined by the creatinine production in the muscles, the glomerular filtration rate, and the tubular secretion of creatinine, the latter accounting for $35-50 \%$ of renal excretion [23]. The continuous increase of urinary creatinine is probably mainly caused by the increasing amount of creatinine produced by the growing muscle mass. At the age of 2 weeks the scattering of the urinary creatinine concentration increased due to variable water intake. After weaning, the urinary creatinine concentration is mainly determined by the creatinine production in the muscles, the drinking behavior of the mice, and by the fully developed ability of the animals to produce concentrated urine.

\section{Postnatal Salt-Wasting in KCNJ10-/- Mice}

Patients, homozygous for loss-of-function mutations of the potassium channel KCNJ10 (Kir4.1), suffer from EAST or SeSAME syndrome, a complex autosomal recessive disorder that is characterized by epilepsy, ataxia, sensorineural deafness, variable degrees of mental retardation, and a salt-wasting renal tubulopathy $[13,14,24,25]$. As a model for this human disease, we investigated the urinary salt excretion of $\mathrm{KCNJ} 10^{-/-}$mice. $\mathrm{KCNJ} 10^{-/-}$ mice displayed the expected urinary loss of $\mathrm{Na}^{+}$and $\mathrm{K}^{+}$ and the reduced excretion of $\mathrm{Ca}^{2+}$ [13]. In addition, the profile of urinary excretion during the first 6 postnatal days disclosed a strong age dependence that hampers renal phenotyping of these mice.

\section{Concluding Remarks}

The knowledge of the time course of ion excretion is highly relevant for the interpretation of knockout mice data. The most pronounced changes of renal ion excretion take place directly after birth and during the weaning period. Therefore, the phenotypic examination of knockout mice models during these critical phases has to be performed very carefully. To avoid these phases of very high variability, we suggest to phenotype mice between postnatal days 4 and 12 and to use strictly age-matched animals or littermates. 


\section{Acknowledgement}

The study was supported by the Deutsche Forschungsgemeinschaft, SFB699, to M. Reichold and R. Warth.

\section{Disclosure Statement}

The authors have no conflicts of interest to disclose.

\section{References}

$\checkmark 1$ Meneton P, Ichikawa I, Inagami T, Schnermann J: Renal physiology of the mouse. Am J Physiol Renal Physiol 2000;278:F339-F351.

$\checkmark 2$ Fenton RA, Knepper MA: Mouse models and the urinary concentrating mechanism in the new millennium. Physiol Rev 2007;87:10831112.

3 Takahashi N, Chernavvsky DR, Gomez RA, Igarashi P, Gitelman HJ, Smithies O: Uncompensated polyuria in a mouse model of Bartter's syndrome. Proc Natl Acad Sci USA 2000; 97:5434-5439.

-4 Lorenz JN, Baird NR, Judd LM, Noonan WT, Andringa A, Doetschman T, Manning PA, Liu LH, Miller ML, Shull GE: Impaired renal $\mathrm{NaCl}$ absorption in mice lacking the ROMK potassium channel, a model for type II Bartter's syndrome. J Biol Chem 2002;277:37871-37880.

5 Yang B, Gillespie A, Carlson EJ, Epstein CJ, Verkman AS: Neonatal mortality in an aquaporin-2 knock-in mouse model of recessive nephrogenic diabetes insipidus. J Biol Chem 2001;276:2775-2779.

6 Yun J, Schoneberg T, Liu J, Schulz A, Ecelbarger CA, Promeneur D, Nielsen S, Sheng H, Grinberg A, Deng C, Wess J: Generation and phenotype of mice harboring a nonsense mutation in the V2 vasopressin receptor gene. J Clin Invest 2000;106:1361-1371.

-7 Berger S, Bleich M, Schmid W, Greger R, Schutz G: Mineralocorticoid receptor knockout mice: lessons on $\mathrm{Na}^{+}$metabolism. Kidney Int 2000;57:1295-1298.

${ }_{8}$ Bleich $\mathrm{M}$, Warth $\mathrm{R}$, Schmidt-Hieber M, Schulz-Baldes A, Hasselblatt P, Fisch D, Berger S, Kunzelmann K, Kriz W, Schütz G, Greger R: Rescue of the mineralocorticoid receptor knock-out mouse. Pflugers Arch 1999; 438:245-254.

-9 Satlin LM: Maturation of renal potassium transport. Pediatr Nephrol 1991;5:260-269.

10 Falk G: Maturation of renal function in infant rats. Am J Physiol 1955;181:157-170.

11 Bandulik S, Tauber P, Penton D, Schweda F, Tegtmeier I, Sterner C, Lalli E, Lesage F, Hartmann M, Barhanin J, Warth R: Severe hyperaldosteronism in neonatal Task3 potassium channel knockout mice is associated with activation of the intraadrenal renin-angiotensin system. Endocrinology 2013;154:2712-2722.

$\checkmark 12$ Kofuji P, Ceelen P, Zahs KR, Surbeck LW, Lester HA, Newman EA: Genetic inactivation of an inwardly rectifying potassium channel (Kir4.1 subunit) in mice: phenotypic impact in retina. J Neurosci 2000;20:5733-5740.
13 Bockenhauer D, Feather S, Stanescu HC, Bandulik S, Zdebik AA, Reichold M, Tobin J, Lieberer E, Sterner C, Landoure G, Arora R, Sirimanna T, Thompson D, Cross JH, van't Hoff W, Al MO, Tullus K, Yeung S, Anikster Y, Klootwijk E, Hubank M, Dillon MJ, Heitzmann D, Arcos-Burgos M, Knepper MA, Dobbie A, Gahl WA, Warth R, Sheridan E, Kleta R: Epilepsy, ataxia, sensorineural deafness, tubulopathy, and KCNJ10 mutations. N Engl J Med 2009;360:1960-1970.

14 Scholl UI, Choi M, Liu T, Ramaekers VT, Hausler MG, Grimmer J, Tobe SW, Farhi A, Nelson-Williams C, Lifton RP: Seizures, sensorineural deafness, ataxia, mental retardation, and electrolyte imbalance (SeSAME syndrome) caused by mutations in KCNJ10. Proc Natl Acad Sci USA 2009;106:5842-5847.

15 Knight CH, Maltz E, Docherty AH: Milk yield and composition in mice: effects of litter size and lactation number. Comp Biochem Physiol A Comp Physiol 1986;84:127-133.

16 Nicholas KR, Hartmann PE: Milk secretion in the rat: progressive changes in milk composition during lactation and weaning and the effect of diet. Comp Biochem Physiol A Comp Physiol 1991;98:535-542.

17 Keen CL, Lonnerdal B, Clegg M, Hurley LS: Developmental changes in composition of rat milk: trace elements, minerals, protein, carbohydrate and fat. J Nutr 1981;111:226-236.

18 McCarty R, Tong H: Milk electrolyte content of Dahl hypertensive and normotensive rats. Physiol Behav 1995;57:477-481.

19 Martinerie L, Viengchareun S, Delezoide AL, Jaubert F, Sinico M, Prevot S, Boileau P, Meduri G, Lombes M: Low renal mineralocorticoid receptor expression at birth contributes to partial aldosterone resistance in neonates. Endocrinology 2009;150:4414-4424.

20 Lelievre-Pegorier M, Merlet-Benichou C, Roinel N, de Rouffignac C: Developmental pattern of water and electrolyte transport in rat superficial nephrons. Am J Physiol 1983; 245:F15-F21.

21 Gaull G, Sturman JA, Raiha NC: Development of mammalian sulfur metabolism: absence of cystathionase in human fetal tissues. Pediatr Res 1972;6:538-547.

22 Guillery EN, Huss DJ: Developmental regulation of chloride/formate exchange in guinea pig proximal tubules. Am J Physiol 1995; 269:F686-F695.
23 Eisner C, Faulhaber-Walter R, Wang Y, Leelahavanichkul A, Yuen PS, Mizel D, Star RA, Briggs JP, Levine M, Schnermann J: Major contribution of tubular secretion to creatinine clearance in mice. Kidney Int 2010;77:519-526.

24 Bandulik S, Schmidt K, Bockenhauer D, Zdebik AA, Humberg E, Kleta R, Warth R, Reichold M: The salt-wasting phenotype of EAST syndrome, a disease with multifaceted symptoms linked to the KCNJ10 $\mathrm{K}^{+}$channel. Pflugers Arch 2011;461:423-435.

25 Freudenthal B, Kulaveerasingam D, Lingappa L, Shah MA, Brueton L, Wassmer E, Ognjanovic M, Dorison N, Reichold M, Bockenhauer D, Kleta R, Zdebik AA: KCNJ10 mutations disrupt function in patients with EAST syndrome. Nephron Physiol 2011;119:40-48.

26 Meier H, Hoag WG, McBurney JJ: Chemical characterization of inbred-strain mouse milk. I. Gross composition and amino acid analysis. J Nutr 1965;85:305-308.

27 Meier H, Hoag WG, McBurney JJ, Myers DD: Chemical characterization of imbred strain mouse milk. II. Total fatty acids and fatty acid analyses. Proc Soc Exp Biol Med 1967;124: 633-636.

28 Kumar S, Clarke AR, Hooper ML, Horne DS, Law AJ, Leaver J, Springbett A, Stevenson E, Simons JP: Milk composition and lactation of $\beta$-casein-deficient mice. Proc Natl Acad Sci USA 1994;91:6138-6142.

29 Boumahrou N, Andrei S, Miranda G, Henry C, Panthier JJ, Martin P, Bellier S: The major protein fraction of mouse milk revisited using proven proteomic tools. J Physiol Pharmacol 2009;60(suppl 3):113-118.

30 Reis BL, Keen CL, Lonnerdal B, Hurley LS: Longitudinal changes in the mineral composition of mouse milk and the relationship to zinc metabolism of the suckling neonate. J Nutr 1991;121:687-699.

31 Berga SE, Neville MC: Sodium and potassium distribution in the lactating mouse mammary gland in vivo. J Physiol 1985;361:219-230.

32 Riley LG, Zubair M, Thomson PC, Holt M, Xavier SP, Wynn PC, Sheehy PA: Lactational performance of Quackenbush Swiss line 5 mice. J Anim Sci 2006;84:2118-2125.

-33 Allen JC: Effect of vitamin D deficiency on mouse mammary gland and milk. J Nutr 1984;114:42-49.

-34 Delzer PR, Meyer RA Jr: Normal milk composition in lactating X-linked hypophosphatemic mice despite continued hypophosphatemia. Calcif Tissue Int 1983;35:750-754.

- 35 Koo WW, Gupta JM: Breast milk sodium. Arch Dis Child 1982;57:500-502. 